\title{
The urgency of local act draft on corporate social responsibility (CSR) in Way Kanan
}

\author{
Charlyna S. Purba ${ }^{1 *}$, Yenny A.S ${ }^{2}$ \\ 1, 2 Faculty of Law, Universitas Panca Bhakti Pontianak, Pontianak, Indonesia
}

\section{Key Words}

Urgency

Local act draft

Corporate social responsibility

Received: 2 October 2016

Accepted: 5 March 2017

Published: 21 April 2017

\begin{abstract}
This research would answer the question about the significance of the urgency. Normative method research and work method would be employed, which include: (1) collecting data and information (rules, books, seminar, research or other references, website and interview); (2) substance and information compilation; (3) Assessment and analyzing (Focus Group Discussion/FGD); and (4) the preparation of the subject matter of an academic paper (analytical descriptive form). The theory development of this research would be implicated in constitutional law, whereas practically the Local Act Draft on CSR will be implemented in Way Kanan. The result represented that Local Act Draft on CSR arranged by the companies program's legal certainty and legal protection purposes and provide guidance for all of the companies and even stakeholders to work together with Way Kanan Local Government for development program. That is why, Way Kanan Local Government will need to review and prepare the regulation regents.
\end{abstract}

(C)2017 The Author. Publsihed by TAF Publishing.

\section{INTRODUCTION}

Industrial development does not only explore a variety of company potential goods for companies finance at the present time, but also highlight the social relation between companies and communities around the company. Corporate Social Responsibility (CSR) implementation is a forum for companies to show their existences in community and for environment concernce that receive the natural resource management impact. Therefore, CSR become the company obligation in running out its business related to natural resources.

Although in developed countries CSR issue has been long enough appeared, but it was still quite intense discussed in Indonesia (Badarudin, 2008). The response to the importance of CSR could be seen from the issuance of government policy through the Minister of State-Owned Enterprises No. KEP-236/MBU/2003 required that all state companies set a side part of their profits for community development, known as the Partnership Program and Community Development (first term for CSR). The implementation was known through the Circular Letter Minister of State, SE No. 433/MBU/2003 as an indication its implementation mentioned above. Furthermore, visible through the issuance of Act No. 40 of 2007 on Incorporated Company and Government Regulation No. 47 of 2012 on CSR and Environmental of Incorporated Company.

According to Art 74 Act No. 40 of 2007 on Incorporated Company contains some company duties, especially the exploration of natural resources by companies in doing CSR as

\footnotetext{
*Corresponding author: Charlyna S. Purba

${ }^{\dagger}$ Email: charlyna.purba@gmail.com
} 
the following statements:

a. Incorporated company in running out the activity related to natural resources is duty to organize CSR and Environmental;

b. CSR and Environmental as mentioned in paragraph (1) is company duty, budgeted and calculated by incorporated environment cost where the implementation regarding decency and equity;

c. Sanction is subjected for company which did not obey paragraph (1) stated on legislation act; and

d. Further law on CSR and Environmental is regulated by Government Regulation.

Act No. 40 of 2007 on Incorporated Company conclude several things as including:

a. CSR is an obligation for company to manage business activities and exploit natural resources or the company does not manage and use natural resources, but its business activities have an impact on natural resources capability function;

b. CSR implementation is included by company cost;

c. CSR implementation is regarding on decency and fairness principle;

d. Penalties are given to company which did not carry out CSR as sanction imposed by legislation concerned; and

e. CSR is based on the balance relation due to company, environmental and social.

Then, Government Regulation No. 47 of 2012 on CSR and Environmental of Incorporated Company is issued by Article 74 paragraph (4) Act No. 40 of 2007 on Incorporated Company executant. Article 2 Government Regulation No. 47 of 2012 on CSR and Environmental of Incorporated Company states that "Every company as a legal subject have a social responsibility and environmental." This provision confirms that basically every company as a form of human activity in business, morally committed to be responsible create company's harmonious, balance with environment and local communities in accordance with value, norm and society culture are indirectly support local community development.

Given the implementation of CSR is part of the national development efforts in order to reach national objectives, the involvement of local governments, is important to provide legal certainty in local CSR implementation. Released by Way Kanan District (Way Kanan) official website, the economy development in Way Kanan was supported by industrial, agricultural and trading sector (Widjaja, 2005). The labor market in Way Kanan during the period 2012-2014 was marked by a labor force participation rate (TPAK) "67,75\%" (2012); "69,50\%" (2013); then increased to "71,27\%" (2014). When it observed, the composition of the agricultural sector was still dominated with "79\%", followed by the service "24\%" and industrial sector (7\%). Based on the potential examination for economic development in Way Kanan, the companies engaged in various sectors to demonstrate their existances for local community and considered their activities impact on the environment surrounding. CSR is expected as a meant of embedding relationships between companies and local communities in business for the sake of company issues emphasis around the company (Alshannag et al., 2017; Hosban, 2016). Thus, in order to create a synergistic relationship between local government, the company and all the people in Way Kanan need CSR programs implementation law arrangement is necessary in Way Kanan related to CSR. This research will be a first step to determine the urgency of Local Act Draft on CSR in Way Kanan. The analysis of "The Urgency of Local Act Draft on CSR in Way Kanan" was a step in providing a depth comprehensive assessment and legal consideration to determine the establishment urgency of Local Act Draft on CSR in Way Kanan. This research will contribute in setting Local Act Draft on CSR that will be implicate in Way Kanan: 
1. Formulated the problems faced related to CSR in Way Kanan and ways to overcome these problems.

2. Formulated the legal issues faced as the reason for the establishment of Local Act Draft on CSR in Way

Kanan as legal basis for the settlement or solution of problems related CSR.

3. Formulated the consideration of philosophical, sociological and juridical establishment of Local Act Draft on CSR in Way Kanan.

4. Formulated the goals would be realized, the scope of the regulation, the scope and direction of the setting in Local Act Draft on CSR in Way Kanan.

The usefulness of the Academic Paper of Local Act Draft on CSR for:

1. For consideration which could be used in the formation of the initiative proposal Local Act Draft on CSR in Way Kanan companies will be discussed.

2. As a basic material of Local Act Draft forming on CSR in Way Kanan.

3. As an official document which will attach to the concept Local Act Draft on CSR in Way Kanan that would be discussed.

\section{LITERATURE REVIEW}

CSR perspectives comes from the two points of view that the role of business in society (Branco and Lúcia, 2007). The first perspective, classical view (shareholder perspective) which based on neo-classical economic theory, looked at the role of business in society purely as a search for profit, ie profit for the shareholder. Instead, stakeholder view which based on stakeholder theory, believed that the company have a social responsibility. Social responsibility required companies had a social responsibility and considered the interests of all parties affected by its actions.

Another view proposes that CSR involves four categories of social responsibility (Carroll, 1979), namely:

(i) Economic responsibility, reflected beleiveness that the company have an obligation to produce the goods and services required by customers and would bring benefits in the process.

(ii) The legal responsibility, indicated that the company was expected to fulfill their economic responsibilities in the lawsuit says.

(iii) The ethical responsibility, showed a concern that companies met society's expectations of business actions were not codified into law, but rather as reflected in the standards, norms, unwritten values implicitly derived from the public.

(iv) Diskresionaris responsibility, the company was philanthropic or voluntary, in sense that this responsibility represented the company voluntary role of people expectations whose was not as clear as in the ethical responsibilities. Diskresionaris ethical responsibility and involve more responsibilities to do what good and avoided injury or damage was.

The relation between these responsibilities appear as a pyramid where the economy is the basic for three other responsibilities, legal responsibility is the basic for two other responsibilities and so on. According to Carroll (1979) the company have to fill four responsibilities simultaneously. The main assumption behind this perspective that the economic problem is the responsibility of community business, was not only a matter of company or business concerned.

RESEARCH MODEL

This writing method used normative research/dogmatic legal research (Suratman and Philips, 2013) to describe the object of research through interpretation, analysis and law 
construction. Data were collected through library research method related to CSR.

\section{DISCUSSION}

Implementation Practical Analysis, Condition and Problem

Way Kanan District with Blambangan Umbu capital was risen by North Lampung District (North Lampung). Officially formed on April 20 of 1999 based on Act No. 12 of 1999 on The Establishment of Way Kanan District, East Lampung District and Metro City. In the early, Way Kanan comprised in 6 (six) definitive sub-districts and 192 (one hundred ninety two) villages. Then, sub-district increased to 12 (twelve) sub-districts and 198 (one hundred ninety eight) villages in 2003. Finally, the inssuanced of Local Act No. 3 of 2005 on The Establishment of both Karya Maju Village and Mulya Jaya Village in Rebang Tangkas SubDistrict, 14 sub-district and 210 villages totally.

Geographically, Way Kanan is in 104,170-105,040 East Longitudinal dan 4,120-4,580 South Latitude in the following borderlines:

- North : South Sumatra and Bengkulu

- South : North Lampung

- West : West Lampung

- East : West Tulang Bawang

The election of Umbu Blambangan as Way Kanan capital becaused its strategic location in Way Kanan center that would be easier in local monitoring. In addition, Blambangan Umbu is in traffic to South Sumatra. Market labor in Way Kanan during the period 2012-2014 was marked by a labor force participation rate (TPAK) which liable increased in $67.65 \%$ (2012), 69.50\% (2013) and 71.27\% (2014). When observed by work field composition, the agricultural sector was still dominated, employment percentation reached until $79 \%$ followed by services sector (14\%) and industry (7\%). According to jobs composition employment absorption in Way Kanan, it was dominated by agricultural sector (79\%), service sector $(14 \%)$ and industrial sector in (7\%). It proved that Way Kanan economy was supported by industrial, agricultural and trade sector as follows:

\section{a. Industrial Sector:}

Industry growing in Way Kanan was produced by plantation and agricultural, such as cassava, palm oil, pineapple canning and rubber plants.

\section{b. Agricultural Sector:}

(1) Horticulture

Way Kanan has a huge horticulture potential to be developed, especially orange, pineapple and banana.

(2) Livestock

Livestock population has developed in Way Kanan for local and interlocal consumption include cow, goat, duck, pig, sheep, hen and chicken. Farm existence was supported by agricultural availability as a source of livestock feed. In addition, rubber and oil palm were owned by government, private and community sector in Way Kanan. Grass production grew in crevices tree, both rubber and palm oil reached 250,000 tons/year so as to accommodate 22,772 ST/year equivalent to 22,772 adult cows. Agro-industry existence including mill tapioca, sugar cane factories, rice cultivation and processing of pineapple are livestock feed production its good development due to large livestock animal, small and poultry.

(3) Fisheries

Fisheries potential in Way Kanan was supported by 2 (two) main activities, both the activities of aquaculture and captured fisheries in public waters. Although Way Kanan does 
not have marine fisheries potential, but the general water fisheries potential and capturing fisheries are prospective enough.

There are several potential locations to be used as development location of the development, the Way Kanan river, Way Umbu, Way Besai, Way Giham and Way Tahmi. There is a potential location provided for aquaculture in Banjit, Baradutu and Bahuga with commodity types such carp, tilapia and catfish.

(4) Plantation

Plantation is one of the potential sectors is covered by $145.989,30$ hectares with $245.380,60$ tons/year of total crop plantation production. It consist of rubber, oil palm, coconut, hybrid coconut, coffee, pepper, cocoa and clove especially rubber, oil palm, cocoa and coffee. Rubber plantation development center located in Blambangan Umbu, Negeri Agung, Way Tuba, Pakuon Ratu, Negeri Besar dan Negara Batin. Plantation development center spread in almost of Blambangan Umbu, Negeri Agung, Way Tuba, Pakuon Ratu, Negeri Besar, Negara Batin, Bahuga, Bumi Agung dan Buay Bahuga. Coffee plantation development center scattered in Banjit, Kasui, Rebang Tangkas, Baradatu dan Gunung Labuhan. Pepper plantation development center spread in Banjit, Kasui, Rebang Tangkas, Baradatu dan Gunung Labuhan. Cocoa plantation development center scattered in Banjit, Kasui, Rebang Tangkas, Baradatu and Gunung Labuhan.

(5) Forestry

Potential forestry area are 89.286 .42 hectares. Forestry area produces a various types of wood likely a mixture of jungle wood, teak, albizia, acacia mangium and other non-timber forestry products. Investment opportunities can develop in forestry sector include reactivating industrial forest area of 53.554.58 hectares forest area located in Rebang register, Muara Dua and Way Hanakau on the former area of PT. Inhutani V which experien liquidity, construction and development of forest product processing industry in the form of timber and non-timber and environmental services utilization of forest areas for ecotourism.

\section{Trade Sector}

Way Kanan traversed road along the ocean, railway crossing regional supported by Way Tuba airfield presence have potential trade and services sectors development in the region. Development of trade and services in Way Kanan is more to facilitate the production and transaction of commodity crop, food crop, forestry, animal husbandary and fishery.

Based on an examination of economic development potential in Way Kanan, the companies engaged in various sectors must continue to demonstrate its existence for the local community and also consider the impact of its activities on the surrounding environment. The reason is a company is ideally give benefit for surrounding communities, CSR was expected in addition to empowering local people as well as a company effort to operate to run company smoothly without interruption. It is mean that embedding relationship between companies and local communities in running the business for the sake of emphasis on issues around the company.

Therefore, to facilitate the company commitment or the business world in order to contribute in economic development with a sustainable balance between economic, social and environmental related adjustment is needed in the area of social responsibility Way Kanan. Thus, the necessary of concrete step will be included in a Local Act Draft on CSR in Way Kanan as Local Legislative initiative. 


\section{Assessment Principles}

The principles of the rule of law likely a bridge connecting the regulations with the ideal of social and ethical views of society to be arranged. The Academic Paper of Local Act Draft on CSR in Way Kanan would be adjusted by the related principles. Article 5 Act No. 12 of 2011 on the Establishment of Legislation stated that the principle of the establishment of good legislation include the principles of clarity of objectives; appropriate official/institution; correspondence between types, hierarchy, and material content; can be implemented; usability and outcome; clarity of formulation; and openness. Meanwhile, the content of Article 6 paragraph (1) of this act clearance that the substance of the legislation have to reflect the principle of aigis; humanity, nationality; kinship; archipelago; culturally diverse, justice; equality before the law and governance; order and legal certainty; and balance.

The principles of the legislation formation is necessary to implement because in this era of broad autonomy occur forming local regulations make a rule just on the basis of intuition and not for the company needs accordance with the arrangements Article 237 paragraph 1 of Act No. 23 of 2014 on Local Governance said that "the principle of the formation and the substance of legislation guided by the provisions of legislation and legal principles that grew and develope in society is not contrary to the principle of the Unitary Republic of Indonesia".

In line with this, Article 2 of Act No. 40 of 2007 on Limited Liability regulated all business activities, including activities related to CSR programs should not conflict with the provisions of law, public order and/or decency. Therefore, Local Act Draft on CSR in Way Kanan will include the principle of legal certainty, the common good, solidarity, participatory and aspirational, openness, sustainability and environmental insight, independence and balance of progress and national economic unity with the intention of giving certainty and legal protection for the organization CSR in Way Kanan and gave direction to all companies and all stakeholders on the implementation of CSR programs in synergy with Way Kanan Local Government development programme in achieving the following objectives: 1. The establishment of clear provisions on CSR.

2. The fulfillment of the implementation of CSR in accordance with the legislation in force in a co-ordination force.

3. Realization of legal certainty and protection for the company in the implementation of CSR integratedly and efficiently.

4. Protect the company in order to avoid widespread extortion parties not authorized.

5. Negative impact minimizing of the company's presence and positive impact optimizing of the company's existence; and

6. Local Government CSR awards to conduct appreciation in CSR implementation.

\section{Evaluation of Law}

Evaluation and analysis of the legislation is intended to determine the law or regulation condition substance or material related to this Local Act Draft on CSR in Way Kanan will establish. This analysis describe the laws and regulations synchronization and harmonization with other exist regulations to avoid the overlapping and provide the foundation authority to the regions clearly and unambiguously.

The law and regulation provisions regarding to CSR are synchronize with Way Kanan Local Government authorities in making Local Act Draft on CSR as following:

(1) Authority: Pursuant to the Way Kanan Local Government authority, the preparation of Academic Paper of Local Act Draft on CSR in Way Kanan in order to implement the authority are contained by: 
a. Art 20A point (1) of 1945 Constitution of Republic Indonesia; and

b. Art 33 of 1945 Constitution of Republic Indonesia.

(ii) Act No. 2 of 2015 on Stipulation of Government Regulation in Lieu of Act No. 2 of 2014 on the Amendment to Act No. 23 of 2014 on Regional Government becomes Law

a. Act No.23 of 2014 on Regional Government as mention in the following point:

i. Art 1 (6) Act No. 23 of 2014 on Regional Government;

ii. Appendix point (e) Act No. 23 of 2014 on Regional Government;

iii. Appendix point (k) Act No. 23 of 2014 on Regional Government;

iv. Appendix point (r) Act No. 23 of 2014 on Regional Government;

v. Appendix point (ee) Act No. 23 of 2014 on Regional Government;

vi. Art 148 (1) Act No. 23 of 2014 on Regional Government;

vii. Art 149 Act No. 23 of 2014 on Regional Government; and

viii. Art 150 Act No. 23 of 2014 on Regional Government.

b. Art 154 Act No. 2 of 2015 on Stipulation of Government Regulation in Lieu of Act No. 2 of 2014 on the Amendment to Act No. 23 of 2014 on Regional Government becomes Law (iii) Government Regulation No. 38 of 2007 on the Division of Government Affairs between the Government, Provincial Government and District/City Government.

a. Art 6 until Art 12 Government Regulation No. 38 of 2007 on the Division of Government Affairs between the Government, Provincial Government and District/City Government; b. Appendix point (u) Government Regulation No. 38 of 2007 on the Division of Government Affairs between the Government, Provincial Government and District/City Government;

c. Appendix point (p) Government Regulation No. 38 of 2007 on the Division of Government Affairs between the Government, Provincial Government and District/City Government;

d. Appendix point (z) Government Regulation No. 38 of 2007 on the Division of Government Affairs between the Government, Provincial Government and District/City Government;

e. Appendix point (dd) Government Regulation No. 38 of 2007 on the Division of Government Affairs between the Government, Provincial Government and District/City Government; and

f. Appendix point (ee) Government Regulation No. 38 of 2007 on the Division of Government Affairs between the Government, Provincial Government and District/City Government.

(2) Procedure: Based on the law and regulation procedures related to CSR, Local Act Draft on CSR are organized by the following provisions

(i) Act No. 22 of 2001 on Oil and Gas

a. Art 11 (3) point p Act No. 22 of 2001 on Oil and Gas; and

b. Art 40 (5) Act No. 22 of 2001 on Oil and Gas

(ii) Art 88 (1) Act No. 19 of 2003 on State Owned Enterprises

(iii) Act No. 25 of 2007 on Investment

a. Art 15 point b Act No. 25 of 2007 on Investment;

b. Art 16 Act No. 25 of 2007 on Investment;

c. Art 34 Act No. 25 of 2007 on Investment; and

d. Art 34 (3) Act No. 25 of 2007 on Investment.

(iv) Art 15 point b Act No. 4 of 2009 on Mineral and Coal Mining

(v) Art 68 Act No. 32 of 2009 on Protection and Environmental Management

(vi) Act No. 21 of 2014 on Geothermal 
a. Art 52 (1) point g Act No. 21 of 2014 on Geothermal; and

b. Art 65 (2) Act No. 21 of 2014 on Geothermal.

(vii) Regulation of the Minister for State Owned Enterprises No. PER-05/MBU/2007 on Partnership Program State Owned Enterprises with Small Business and Community Development Program as amended by Regulation of the Minister of State-Owned Enterprises No. 8 of 2013 regarding Fourth Amendment to the Regulation of the Minister of State State Owned Enterprises No. 5 of 2007 concerning Partnership Program State Owned Enterprises with Small Business and Community Development Program

(3) Substance: Conditions substance to be contained in a Local Act Draft on CSR in Way Kanan district is governed by the following rules:

(i) Act No. 40 of 2007 on Incorporated Company

a. Art 1 (3) Act No. 40 of 2007 on Incorporated Company; and

b. Art 74 Act No. 40 of 2007 on Incorporated Company.

(ii) Art 2 Government Regulation No. 47 of 2012 on Social Responsibility and Incorporated Company Circle

\section{The Cornerstone of Philosophical, Sociological and Juridical}

(1) Philosophical: Philosophical foundation is the basic idea of the views or ideals while pouring passion and wisdom to the draft plan or state regulations (Lubis, 1995; Ambikai and Zahira, 2016). In this case, the philosophical values of the Republic of Indonesia Pancasila as staatsfundamentalnorm and the Constitution 1945 is reflected in the legislation form.

In accordance with Constitution 1945 and Pancasila, the state government administration was based and governed by the provisions of the Constitution and other legal provisions, namely legislation, government regulations, local regulations, and other legal provisions are determined democratically and constitutionally. It implies that the administration of the country through various state government policies continued to be based and digested through legal provisions democratically controlled. Democratic state administration implemented with emphasis on the balance between the duties, authority, responsibility, and obligation, in managing and running the government. Theoretically the system of government is known as a decentralized system, contain two basic elements, namely the formation of autonomous regions and autonomous regions.

Local Government can organize and manage the affairs of government in accordance with the principle of autonomy and duty of assistance, aimed at achieving the welfare of the community, through improvement, service, empowerment and community participation, as well as increased competitiveness of the region with regard to the principles of democracy, equality, justice, and specificities of the region within the Unitary State of the Republic of Indonesia (Widjaya, 2005). Local Act Draft on CSR in Way Kanan is intended by providing legal certainty and legal protection for administering CSR program and provides a guidance to all of the firms and all stakeholders on CSR implementation programs instead of working cooperatedly with Way Kanan Local Government development programme.

(2) Sociological: In order to facilitate the commitment of the company or business world to develop the economic in a sutainable balance between economis, social and environmental related adjustment is needed in Way Kanan CSR implementation. Thus, the concrete step would be included in a Local Act Draft on CSR in Way Kanan.

Sociological regarding the enforceability of any legislation likely to prefer an empirical approach by prioritizing some selection criteria (Asshiddiqie, 2011), namely:

(i) Recognition theory criteria in Local Act Draft draft Way Kanan is related to the extent 
of legal subjects, namely company in Way Kanan, society in Way Kanan and Local Government in Way Kanan (SKPD or authorized official) set acknowledge the existence and power tie and obligation to bind themselves to the legal norms set out in drafting it.

(ii) Reception theory criteria related sociological Local Act Draft on CSR in Way Kanan public awareness regarding company in Way Kanan, society in Way Kanan and Local Government in Way Kanan (SKPD or authorized official) to receive a power-set, power-belt and power-sociological force in organizing CSR program in Way Kanan.

(iii) Facticity criteria of Local Act Draft on CSR in Way Kanan emphasizes the extent to which the rule of law is truly effective in Way Kanan real life society.

Preparation of Local Act Draft on CSR in Way Kanan is based on the priorities and strategic issues as outlined in the policy direction based on community needs in order to draft CSR to be established got "social legitimacy" from society. Thus, by the establishment and implementation of the Local Act Draft on CSR in Way Kanan, will be the legal basic for company in Way Kanan, society in Way Kanan and Local Government in Way Kanan (SKPD or authorized official) in order to provide legal certainty and legal protection for administering CSR program and provides a guidance to all of the firms and stakeholders on CSR implementation program in synergy with Way Kanan Local Government development programme.

(3) Juridical: In order to ensure legal certainty, legal protection and a sense of justice and avoid disharmony and overlapping of Local Act Draft on CSR in Way Kanan as applied in the following juridical foundation:

(i) Constitution of the Republic of Indonesia 1945 (UUD 1945);

(ii) Act No. 12 of 1999 on the establishment of the Regency of Way Kanan Regency, Regency of East Lampung and City Madya Regional II Metro;

(iii) Act No. 22 of 2001 on Oil and Gas;

(iv) Act No. 19 of 2003 on State Owned Enterprises;

(v) Act No. 25 of 2007 on Investment;

(vi) Act No. 40 of 2007 regarding Limited Liability Company;

(vii) Act No. 4 of 2009 on Mineral and Coal Mining;

(viii) Act No. 32 of 2009 on the Protection and Environmental Management;

(ix) Act No. 12 of 2011 on the Establishment of Legislation;

(x) Act No. 21 of 2014 on Geothermal;

(xi) Act No. 2 of 2015 concerning the Stipulation of Government Regulation in Lieu of Law No. 2 of 2014 on the Amendment to Act No. 23 of 2014 on Regional Government becomes law;

(xii) Government Regulation No. 38 of 2007 on the Division of Government Affairs between the Government, Provincial Government and District/City Government;

(xiii) Government Regulation No. 47 of 2012 on Social and Environmental Responsibility Company Limited;

(xiv) Regulation of the Minister for State Owned Enterprises No. PER-05/MBU/2007 on Partnership Program State Owned Enterprises with Small Business and Community Development Program as amended by Regulation of the Minister of State-Owned Enterprises No. 8 of 2013 regarding Fourth Amendment to the Regulation of the Minister of State State Owned Enterprises No. 5 of 2007 concerning Partnership Program State Owned Enterprises with Small Business and Community Development Program;

Reach, Direction Setting Material Content and Scope of Local Act Draft on CSR in Way Kanan. The setting reach of Local Act Draft on CSR in Way Kanan will be the guidelines/norms of behavior for company in Way Kanan, society in Way Kanan and Way Kanan Local Gov- 
ernment (SKPD or authorized official) as well as contain about permissibility, command and prohibition. Local Act Draft on CSR in Way Kanan is expected will be able to achieve the following goals:

(1) The establishment of clear provisions on CSR;

(2) The fulfillment of the implementation of CSR in accordance with the legislation in force in a co-ordination force;

(3) Realization of legal certainty and protection for the company in the implementation of CSR integratedly and efficiently;

(4) Protect the company in order to avoid widespread extortion parties not authorized;

(5) Negative impact minimizing of the company's presence and positive impact optimizing of the company's existence; and

(6) Local Government CSR awards to conduct appreciation in CSR implementation.

In achieving these goals, Local Act Draft on CSR in Way Kanan including the following substances:

(1) The scope, purpose, objective and principle;

(2) Funding;

(3) Company in CSR implementation,

(4) Company rights and duty;

(5) CSR programme;

(6) CSR forum, consist of the Formation, duty and authority; and CSR forum funding;

(7) CSR field work;

(8) Mechanism and procedure for the CSR programme implementation;

(9) CSR target area;

(10) Planning, implementation, monitoring, evaluation and report;

(11) Awards;

(12) The role of Local Government;

(13) Dispute settlement;

(14) Sanction;

(15) Transitional provision;

(16) Closing provision.

It still open the space for enriching the Local Act Draft on CSR in Way Kanan substance, at the same time able to present the community aspirational as the social base of a law product will be applied. Thus, law product establish will be corresponding between law in the book and Way Kanan society legal need.

The application of Local Act Draft on CSR in Way Kanan will have implication on company in Way Kanan, society in Way Kanan and Way Kanan Local Government (SKPD or authorized official) in governance aspect, people lives as well as regional financial burden due to:

(1) Overcome the social problems, such as policy limitation

Local Act Draft on CSR in Way Kanan will overcome the social problem related CSR implementation and the relation between company in Way Kanan, society in Way Kanan and Way Kanan Local Government (SKPD or authorized official).

(2) Relieve/press the problematic behaviour Local Act Draft on CSR in Way Kanan will improve the intensivity the company's involvement in Way Kanan, society in Way Kanan and Way Kanan Local Government (SKPD or authorized official) in CSR implementation becaused of Local Act Draft on CSR in Way Kanan regulate various activity related to CSR implementation.

(3) Determine the new behavior that are eliminate the problem 
Way Kanan Local Government (SKPD or authorized official) require to be more responsive to the company that will organize CSR. In line with CSR implementation, Local Government is charged in maintaining the Local Act Draft on CSR in Way Kanan firmly and consistently to provide legal certainty and legal protection. Local Government also give the direction for all of the companies and staheholders in order CSR implementation is synergy with development programme of Way Kanan Local Government. While, stakeholders or society participation also contribute to the effectiveness of CSR implementation programme in Way Kanan as subject and objectof the Local Act Draft on CSR in Way Kanan establishment.

In addition, the implication of implementation Local Act Draft on CSR in Way Kanan will be loaded several effective and efficient things, including:

(1) The clarity of the norm due to order, prohibition, necessity and contract with the company in Way Kanan, society in Way Kanan and Way Kanan Local Government (authorized official).

(2) The clarity of the subject items, namely company in Way Kanan, society in Way Kanan and Way Kanan Local Government (authorized official).

(3) The clarity of prohibited or ordered behavior, both rights and duty, then prohibition against the company in Way Kanan, society in Way Kanan and Way Kanan Local Government (SKPD or authorized official) in CSR programme implementation.

(4) The clarity of sanctions to be imposed will effect the controlled both of behavior and action against company in Way Kanan, society in Way Kanan and Way Kanan Local Government (SKPD or authorized official).

\section{IMPLICATIONS OF IMPLEMENTING LOCAL ACT DRAFT ON CSR IN WAY KANAN}

The application of Local Act Draft on CSR in Way Kanan will be implicated for all of the companies in Way Kanan, Local Government in Way Kanan (SKPD or authorized official) and societies in Way Kanan burden due to local government aspects, community life and regional financial:

(1) Social problem solving, such limited range of policy: The implementation of Local Act Draft on CSR in Way Kanan will be able to cover all things about CSR implementation and the relationship of the objects are companies in Way Kanan, Local Government (SKPD or authorized official) and societies in Way Kanan.

(2) Problem behavior pressing/eliminate: Local Act Draft on CSR in Way Kanan will improve the intensivity of company'sinvolvement in Way Kanan, Local Government (SKPD or authorized official) and societies in Way Kanan in the implementationod CSR as determine various activities related to CSR implementation in Way Kanan.

(3) Determine some new behaviors that are expected will eliminate the problem: Way Kanan Local Government (SKPD or authorized official) required to be more responsive for company that will organize CSR. Accordingly, the Way Kanan Local Government (SKPD or authorized official) is also required to firmly and consistently enforce local laws that will be created to provide certainty and legal protection for the organization of the program of CSR and provides guidance to all companies and all stakeholders on the implementation of the program of CSR so that it can work together with the development program Way Kanan District Government. While the participation of the public or stakeholders also turut support effective implementation of CSR program in Way Kanan as subject and object of the establishment of the Local Act Draft on CSR in Way Kanan.

In addition, to streamline the effectiveness and efficiency of Local Act Draft implementation on CSR that will be established, it will be loaded several things, including: 
Way Kanan, Local Government in Way Kanan (SKPD or authorized official) as well as Way Kanan Regency society.

b. The clarity of the subject including companies in Way Kanan, Local Government in Way Kanan (SKPD or authorized official) and societies in Way Kanan.

c. The clarity of prohibited or ordered either rights or obligations and prohibitions against company in Way Kanan, Local Government in Way Kanan (SKPD or authorized official) and societies in Way Kanan in CSR program implementation.

d. The clarity of sanctions to be imposed will affect in controlling company actions or deeds Way Kanan, Local Government (SKPD or authorized official) and society in Way Kanan.

\section{CONCLUSION}

Based on the exposure as the previous chapters we can conclude several things, among others:

(1) Local Act Drafting on CSR in Way Kanan was organized with a view to provide legal certainty and legal protection on the delivery of CSR program and provide guidance to all companies and all stakeholders on the implementation of CSR program could synergize with the Local Government development program in Way Kanan.

(2) Local Act Draft on CSR would be established in Way Kanan this Way as instrument guidelines to Companies in Way Kanan, Way Kanan Local Government (SKPD or authorized official) and Way Kanan communities in order to hold CSR programme in Way Kanan. (3) Targets to be realized, the scope of the regulation, the scope and direction of the Local Act Draft on CSR setting in Way Kanan would be included in the substances as followed:

(i) the scope, purposes, objectives and principles;

(ii) Financing;

(iii) Companies implementing in CSR, consisting of rights and companies duty;

(iv) CSR programs;

(v) CSR forum consists of the formation; duty and authority; and funding of CSR forum;

(vi) CSR field work;

(vii) Mechanisms and procedures for the implementation of CSR programs;

(viii) CSR target areas;

(ix) Planning, implementation, monitoring, and reporting evaluation consists of: planning; implementation; reporting; monitoring and evaluation; awards; the role of local government; dispute settlement; sanctions; and transitional provisions;

\section{LIMITATIONS AND RECOMMENDATIONS}

This study held in accordance with the principle of legal certainty, the common good, solidarity, participatory and aspirational, openness, sustainability, environmental friendliness, independence and balance of progress and national economic unity with intention to give certainty and legal protection on the implementation of CSR programs and gives direction to all companies and all stakeholders on the implementation of CSR programs in synergy with the Government development program goal in Way Kanan. This research will be continued in a Local Act Draft on CSR in Way Kanan. Furthermore, Way Kanan Local Government have to examine and prepare local regulations in the form of the decree to support the technical validity of the Local Act Draft on CSR in Way Kanan.

\section{ACKNOWLEDGEMENT}

This research was supported by Local Legislative in Way Kanan initiative in Local Act Draft on Corporate Social Responsibility (CSR) in Way Kanan. 


\section{REFERENCES}

Alshannag, Fadi, Mohamad Yazis AB., and Khairil Faizal K. 2017. The relationship between corporate social responsibility and corporate financial performance; A survey of literature. International Journal of Business and Administrative Studies 3, no. 11: 9-15. D0I: 10.20469/ijbas.3.10002-1

Ambikai, and Zahira Ishan. 2016. Comparative analysis of law on tort of deviant behaviors in Malaysia and India. Journal of Advances in Humanities and Social Sciences 2, no. 4: 243-249. D0I: 10.20474/jahss-2.4.5

Asshiddiqie, Jimly. 2011. Subject law. Jakarta, Indonesia: Rajawali Press Book.

Badarudin. 2008. Implementation of corporate social responsibility to society through utilization potential of social capital. Speech delivered at the Master Besa Fixed Position, Faculty of Political and Social Sciences Political Science, North Sumatra University, Medan, ID.

Branco, Manuel C., and Lúcia Lima R. 2007. Positioning stakeholder theory within the debate on corporate social responsibility. EJBO-Electronic Journal of Business Ethics and Organization Studies 12, no. 1: 5-14.

Carroll, Archie B. 1979. A three-dimensional conceptual model of corporate performance. Academy of Management Review 4, no. 4: 497-505.

Lubis, Solly 1995. Platform and technical regulations. Bandung, ID: PT. Mandar Maju.

Hosban, Atallah A. 2016. Accounting disclosure for stock goods and industrial companies IAS 2-An analytical study of industrial companies listed on the Amman Stock Exchange. International Journal of Business and Administrative Studies 2, no. 2: 24-28. DOI: 10.20469/ijbas.2.10001-2

Mazutis, Daina D., and Natalie Slawinski. 2015. Reconnecting business and society: Perceptions of authenticity in corporate social responsibility. Journal of Business Ethics 131, no. 1: 137-150.

Suratman, H, and Philips Dillah. 2013. Legal research methods. Bandung, ID: Alfabeta.

Widjaja, Haw. 2005. Autonomy in Indonesia in the context of socialization of law no. 32 of 2004 on regional government. Jakarta, ID: RajaGrafindo Persada.

— This article does not have any appendix. - 